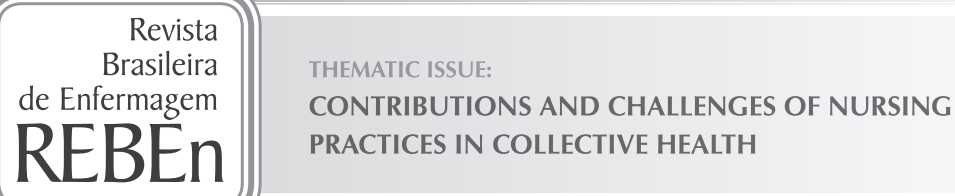

\title{
Obstacles in the detection and reporting of tuberculosis cases: a discursive analysis
}

\author{
Barreiras na detecção e notificação dos casos da tuberculose: uma análise discursiva \\ Barreras en la detección y notificación de los casos de tuberculosis: un análisis discursivo
}

\section{Fernando Mitano', Amélia Nunes Sicsú', Luciana de Oliveira Sousa', Rarianne Carvalho Peruhype', Jaqueline Garcia de Almeida Ballestero', Pedro Fredemir Palha'}

\author{
' Universidade de São Paulo, Nursing School of Ribeirão Preto, Postgraduate Program in Nursing. \\ Ribeirão Preto, São Paulo, Brazil.
}

\begin{abstract}
How to cite this article:
Mitano F, Sicsú AN, Sousa LO, Peruhype RC, Ballestero JGA, Palha PF. Obstacles in the detection and reporting of tuberculosis cases: a discursive analysis. Rev Bras Enferm [Internet]. 2018;71(Suppl 1):523-30. [Thematic Issue:
\end{abstract}

Contributions and challenges of nursing practices in collective health] DOI: http://dx.doi.org/10.1590/0034-7167-2016-0673

\section{Submisson: 03-18-2017 Approval: 08-06-2017}

\begin{abstract}
Objective: To analyze the discourses of health professionals about the obstacles in the process of detection and reporting of tuberculosis cases in Mozambique. Method: Qualitative exploratory study with a theoretical-methodological approach of Discourse Analysis of French matrix. The study was conducted in Mozambique in 2014 at three levels: central, provincial and district. The study included 15 health professionals, 4 physicians, 6 technicians and 5 nursing professionals, who worked in the National Tuberculosis Control Program, with more than 1 year of experience. Result: The following discursive blocks emerged: Detection of tuberculosis cases in laboratories; Underreporting of tuberculosis cases; Obstacles to detect cases of tuberculosis: long distances and lack of transport; and Reporting of cases for decision making. Final considerations: The discourses analyzed point to the ideological affiliation that includes the lack of investment policies in the health sector and the political commitment as basic obstacles in the detection and reporting of tuberculosis cases.
\end{abstract}

Descriptors: Tuberculosis; Social Policy; Health Policy; Health Service; Nursing in Public Health.

\section{RESUMO}

Objetivo: Analisar os discursos dos profissionais de saúde acerca das barreiras no processo de detecção e notificação dos casos de tuberculose em Moçambique. Método: Estudo exploratório qualitativo com abordagem teórico-metodológica da Análise de Discurso de matriz francesa. O estudo foi realizado em Moçambique, no ano de 2014, em três níveis: central, provincial e distrital. Fizeram parte do estudo 15 profissionais de saúde, sendo 4 médicos, 6 técnicos e 5 profissionais de enfermagem, que atuavam no Programa Nacional de Controle da Tuberculose, com mais de 1 ano de experiência. Resultado: Emergiram os seguintes blocos discursivos: Detecção dos casos da tuberculose em laboratórios; Subnotificação dos casos da tuberculose; Barreiras para detecção de casos de tuberculose: longas distâncias e falta de transporte; e Notificação dos casos para a tomada de decisão. Considerações finais: Os discursos analisados apontam para a filiação ideológica que compreende a falta de políticas de investimento no setor da saúde e do comprometimento político como barreiras basilares na detecção e notificação dos casos da tuberculose.

Descritores: Tuberculose; Política Social; Política de Saúde; Serviço de Saúde; Enfermagem em Saúde Pública.

\section{RESUMEN}

Objetivo: Analizar los discursos de los profesionales de salud acerca de las barreras en el proceso de detección y notificación de los casos de tuberculosis en Mozambique. Método: Estudio exploratorio cualitativo con abordaje teórico-metodológico del Análisis de Discurso de matriz francesa. El estudio fue realizado en Mozambique, en el año 2014, en tres niveles: central, provincial y distrital. Quince profesionales de la salud participaron en el estudio, siendo 4 médicos, 6 técnicos y 5 profesionales de enfermería, que actuaban en el Programa Nacional de Control de la Tuberculosis, con más de 1 año de experiencia. Resultado: Los siguientes bloques discursivos emergieron: Detección de los casos de la tuberculosis en laboratorios; Subnotificación de los casos de la tuberculosis; Barreras para la detección de los casos de la tuberculosis: largas distancias y falta de transporte; 
Y notificación de los casos para la toma de decisión. Consideraciones finales: Los discursos analizados apuntan a la filiación ideológica que comprende la falta de políticas de inversión en el sector de la salud y del compromiso político como barreras básicas en la detección y notificación de los casos de la tuberculosis.

Descriptores: Tuberculosis; Política Social; Política de la Salud; Servicio de Salud; Enfermería en Salud Pública.

\section{CORRESPONDING AUTHOR Fernando Mitano E-mail: piqinamita@gmail.com}

\section{INTRODUCTION}

Tuberculosis (TB) is one of the major causes of morbidity and mortality in developing countries such as Mozambique and, for that country, is one of the diseases that kill the most ${ }^{(1)}$. Diagnosis consists of one of the priority actions for TB control, since undiagnosed patients, thus not treated in a timely manner, are the main source of TB transmission ${ }^{(2)}$. Case detection is part of the diagnostic process from the identification of the respiratory symptom to laboratory confirmation. The reporting is an action subsequent to the diagnostic confirmation that allows an accompaniment of the disease, aiming at the dissemination of the information to the management organs in order to assist in the decision making for the control of the disease ${ }^{(1,3)}$. Although several researchers emphasize the importance of detecting and notifying TB cases for disease control ${ }^{(1,46)}$, in Mozambique these actions fall far short of the numbers estimated by the World Health Organization $(\mathrm{WHO})^{(4)}$.

The country is one of the 30 countries that contribute the largest number of TB cases in the world and is included in the select group of countries with incidence greater than 500/100,000 inhabitants ${ }^{(1)}$. The country reported 58,270 new TB cases, corresponding to a reporting rate of 233/100,000 inhabitants in an estimated population of $27,216,000$ in $2015^{(5)}$. However, the number of cases estimated per year by the $\mathrm{WHO}$ is $160,000^{(3)}$, a situation that shows the country's failure to comply with $\mathrm{WHO}$ recommendations, which set the case detection rate at $70 \%$ and cure at $85^{(1)}$ if directly observed treatment of short duration was applied, a strategy that Mozambique began to implement before being recommended by WHO in 1993. Despite using this strategy and demonstrating efforts by the health services in an attempt to control the disease, the country is still unable to detect and report the majority of existing cases, and the 10 countries account for $77 \%$ of the difference ( 4.3 million) between new case reports and the estimated incidence ${ }^{(1)}$.

In a bibliographic survey in the Latin American and Caribbean Health Sciences (LILACS), Scientific Electronic Library Online, (Scielo), PubMed, Scopus and Africa Index Medicus databases, there was a shortage of studies aimed at detection and reporting of TB cases both in the country and internationally, reinforcing the importance of this study, given that it is a topic of great relevance.

In Mozambique, a study on detection emphasized the introduction of the rapid TB test to detect cases mainly in patients affected by HIV/AIDS ${ }^{(7)}$. Studies in several countries, such as Nigeria, Brazil, Afghanistan and Kenya, emphasize case detection and reporting in specific groups such as children, prisoners and people living in rural areas ${ }^{(6,8-8-10)}$. But none explores the discourses of health professionals regarding the detection and reporting of TB cases.
In this context, the understanding of the circulating senses produced among healthcare professionals with experience in the treatment of TB can provide relevant information on the obstacles to the detection and reporting of cases in a highburden country. Thus, the study can contribute to the formulation of policies that improve the detection and reporting of cases. In view of this, the study aims to analyze the discourses of health professionals about the obstacles to the process of detection and reporting of tuberculosis cases in Mozambique.

\section{METHOD}

\section{Ethical aspects}

The survey was approved by the National Ethics Committee of Mozambique in April 2014. Also, the same survey was approved and authorized by the Minister of Health of Mozambique. Participants were informed about the research objectives and about confidentiality/anonymity, confirming their participation through the signing of the Free and Clarified Consent Term. Prior to the start of the survey, all participants were informed of the right to withdraw from the interview at any time if they so wished. In order to preserve the anonymity of the persons who participated in the study, the letter " $\mathrm{S}$ " = subject was used in the presentation of the results, followed by the initial letter referring to the professional category to which the interviewee corresponds ( $\mathrm{M}$ - Manager, $\mathrm{P}$ - Physician, NP - Nursing Professional; MT - Medicine Technician) and an Arabic numeral indicating the sequence of the interviews.

\section{Type of study}

This is a qualitative exploratory study that uses the theoretical-methodological reference of Discourse Analysis (DA) of French matrix, which epistemologically is based on linguistics, psychoanalysis and historical materialism ${ }^{(11)}$.

\section{Theoretical and methodological reference}

This theoretical reference, whose pioneer is Michel Pêcheux, appeared in the 1960s in France as a philosophical current unsatisfied with the positivism installed at the time, which denied the inclusion of conditions of production in the analysis or interpretation of the phenomena under study. The conditions of production can be understood as the historical, social and ideological contexts that permeate a discourse when it is produced ${ }^{(11-12)}$. In this sense, the DA "is intended to highlight the senses of discourse in view of its socio-historical and ideological conditions of production"(12).

Anchored to the aforementioned statement, it can be deduced that the discursive studies aim to think the sense dimensioned in time and in the space of man's practices, decentralizing the 
notion of subject and relativizing the autonomy of the object of linguistics ${ }^{(11)}$. In DA, we understand as subject the positions occupied discursively by the individual enunciator of discourse ${ }^{(11)}$. It is important to point out that individuals when they speak are affiliated to a certain discursive formation, understood as that which in certain ideological conditions is said in one way and not in another. Ideology, on the other hand, is an effect of the necessary relationship of the subject with language and history in the production of meanings ${ }^{(11)}$. In this context, meaning is understood as a determinate relation of the subject affected by language with history ${ }^{(11)}$. Thus, with this approach, one can understand how symbolic objects (signifiers, discursive sequences, cutouts) produce meanings and intervene in the real of meaning.

\section{Methodological procedures}

\section{Study scenario}

The study was conducted in Mozambique, from May to August 2014, at three levels: central, at the Ministry of Health; provincial, in the province of Nampula; district, in eight districts of the province of Nampula (Mecubúri, Murrupula, Muecate, Ribaué, Nampula-Rapale, Meconta, Monapo and Mogovolas).

\section{Data source}

Fifteen health professional subjects were intentionally interviewed by the main researcher, 4 physicians, 6 technicians and 5 nursing professionals, ranging in age from 25 to 55 years, who occupied the positions of managers at different levels (central, provincial and district) . Inclusion criteria were: to be working for more than a year in its role in the National Tuberculosis Control Program (NTCP); and be in the exercise of their activities at the time of data collection.

\section{Collection and data presentation}

For data collection, an interview script was used with the following questions guiding the interview: What are the difficulties faced in the process of detecting and reporting cases? How is the reporting of cases made? How is the flow of information? The questions were previously tested, and the interviews were conducted at locations defined by participants. They were audio-recorded by means of a voice recorder and had an average duration of 30 minutes.

\section{Data analysis}

The interviews were transcribed and the step of returning the transcripts to the participants was waived. For the analysis of the data, the steps proposed by Orlandi ${ }^{(11)}$ were followed: the first one consisted in the passage from the linguistic surface to the discursive object, in which the transcription of the interviews and successive readings were made to identify the ideas of references that belonged to the identified discursive blocks. The second step was to move from the object of discourse to the discursive process, in which the discursive, significant or enunciated sequences that played an important role in the creation of meanings were discriminated against, taking into account the signification process. It is signaled that, at this stage, the discursive sequences were related to the different discursive formations. In the third step, the discursive process itself (ideological formation) returned to the discourse sequences highlighted for analysis, framing itself in a theoretical framework on the subject under study, in a continuous process of discretion and interpretation.

\section{RESULTS}

Four discursive blocks emerged: Detection of TB cases in laboratories; Underreporting of TB cases; Obstacles for detecting TB cases: long distances and lack of transportation; and Reporting of cases for decision-making.

\section{Difficulties in the detection of Tuberculosis cases related to laboratories}

The existence of at least one laboratory in each district of the province is indicated, on the one hand, as important in the TB detection process, but on the other, as insufficient to cover the population demand as it is stated by the subject in the following discursive sequence:

In all districts at least we have a lab, but it looks good, but it's not that good. Let's find a district that says, [...], come on, it has 100,000 square kilometers of area with a laboratory, it's not possible! (MS1)

It is observed that the health professional, taking the position of manager when enunciating the signifiers "at least we have a laboratory", produces senses that impel the cogitation that a laboratory, although insufficient to cover an extensive population area, does not stop being important for case detection and reporting. However, the same signifiers indirectly leave traces of several cases that are not being detected and reported to the national health system in Mozambique.

The adversative conjunction "but" present in the discourse (good and not that good) in the discursive sequence "but it looks good, but it is not that good" leaves the track of double meaning circulating, one that focuses on the positive aspect of the existence of a laboratory in each district, another that emphasizes the need for more laboratories within the districts because the existing ones (one for each district) are not enough. This situation leads to the need to increase laboratories at the district level.

From the discursive sequence "Come on, there's 100,000 km2 of area with a laboratory, it's not possible!", one can identify a discourse of physical geography, indicating the inability of a laboratory to cover a large area occupying about 100 thousand km2 It is emphasized that, although this number $(100,000)$ was randomly stated at the time of the discourse, it originated from the representation of the unconscious, but suggests the greatness of the territory occupied by the districts of Mozambique.

On the laboratories, a speech emerged that focused on the difficulty of acquiring a microscope, an indispensable instrument for the detection of TB in patients:

The main difficulty [...] of these laboratories for TB is related to the acquisition of the instrument that is the microscope, in this case let's talk about the microscopy network that is less available, not to mention the new technologies that are 
even more incipient. [...] the difficulty is to maintain these instruments. The maintenance is generally not local, when failure is necessary to take the microscope to the province and if necessary to request another one [...]. (MS3)

From the discursive sequence "the main difficulty [...] of these laboratories [...] is related to the acquisition of the instrument that is the microscope", the subject-position is observed inscribing itself in a lamenting discursive formation that focuses denouncing the difficulty of the laboratories to function normally. Equally, the same words instigate to think that, although there are buildings established as laboratories, they work with difficulties, because the acquisition of the "microscope" has been a problem. Another saying that indicates the lack of laboratory coverage and the microscope is present in this sequence: "microscopy network that is less available, not to mention new technologies that are even more incipient." This discursive sequence prompts us to consider that the instruments for diagnostic evaluation used are scarce. The signifiers "the difficulty is to maintain these instruments," suggests the lack of trained professionals to maintain the microscope at the district level, which obliges those responsible to take to the provincial level: "it is necessary to take the microscope to the province."

Also in the list of difficulties, subjects state/announce the laboratories as not being suitable for the detection of TB:

[...] infection control because in many laboratories a poorly ventilated small compartment works, it is not possible to process the TB samples while doing another type of activity: sampling other patients while the sample is being processed TB, it is not possible. So we also have problem with the physical location itself, where it works the laboratory does not allow sample processing in some places all day long. (PS4)

From the discursive sequence "[...] in many laboratories small compartments, small windows and few aired windows", it is noticed that the subject-position is inscribed in discursive formations which point the question of the infrastructure as an obstacle to the reporting and treatment of TB. In this context, it is indicated, in these words, the denunciation of infrastructures unfit for the detection and processing of biological material for TB analysis. The same words state/announce the inefficiency of case detection and biosafety, exposing health professionals and users of the health service to an environment conducive to contagion. The sequence also produces meanings that imply that the government is finding it difficult to comply with the guidelines of the NTCP and $\mathrm{WHO}$ recommendations on the sites for the collection of the sputum sample, which should be performed in an airy outdoors, in addition to violating Biosafety standards for the processing of biological samples. These denunciations are characterized by the adjectives "small", "reduced" and adverb of quantity "few".

\section{Underreporting tuberculosis cases}

The low detection and reporting of TB cases, especially in children, emerge as the main guideline in the following discursive cuts, where the subjects are enrolled in discursive formations that focus on underreporting of cases as a barrier to both the reporting system and the treatment.

The difficulty is research, first diagnosis, second follow-up, especially in the south zone of the district; we have three sanitary units with laboratory nearby. The patients we treat there even come from other districts. (MS11)

The lack of inputs has also contributed to low screening because it is not possible to screen for TB without these issues [...] we also feel it is still low tracking in most districts, low $B K+$ case tracking and I do not know [...] would underreport pediatric $T B$, are still having problems in many districts, low TB reporting in children, we know that diagnosis in children is difficult. (PS2)

The signifiers "the difficulty is research", taking into account the conditions of production, produce various effects of meanings that work and mean. Among them, the lack of adequate professionals and means for the detection of TB and the lack of evidence-based studies recommending health practices that compete for the control of TB.

The complaint made by the professional health subject-position is notorious: "the lack of inputs has also contributed to the low level of attention." This discursive sequence suggests the existence of diagnostic difficulties; of TB control; the lack of implementation of a policy capable of controlling TB, and a system of detection and reporting that mirrors the reality of existing cases. Under these production conditions, the sequence suggests that these difficulties have become cyclical, interfering negatively in TB control in the country.

It is noteworthy that the words "low TB reporting in children; we know that diagnosis in children is difficult "and" children's TB means the investigation is not enough "leave within their lines the possibility of considering that subjects state/announce not only the low detection of cases in children but also in adults.

\section{Obstacles to tuberculosis cases: long distances and lack of transport}

Health professionals state/announce the lack of transportation and long distances traveled by patients seeking health care as one of the situations that negatively influences the detection and reporting of TB cases as can be deduced from the following discursive cutbacks:

The major difficulties are many [...] mainly of transport. (MS13)

The main problem is transport as we get to the units when our access roads are damaged? (NPS5)

We know that in the Mozambican reality most of the inhabitants live, we speak of approximately 40 to $45 \%$ of inhabitants who live more than $8 \mathrm{~km}$ from the nearest health unit. (NPS6)

[...] one of them is the distances, and some patients live very far away. (MTS15) 
Added to the problem of distances is the lack of laboratories, which requires the patient to look for the health unit with conditions to perform the TB test:

People go to the hospital, they do not have a laboratory, they are indicated to go to other health units, but the patients do not have money to transport them. (MTS8)

It is observed that the professional health subjects are inscribed in discursive formations of the lamenting speech that focuses the lack of transportation as one of the obstacles in the control of TB and the detection of the cases. It is also noted that this lack of transportation is associated with other faults: "the major difficulties are many". This discursive sequence, considering the socio-historical, economic and ideological conditions of Mozambique, instigates to think that the lack of means of transport is not simply a matter of cars, buses, but other means known to the population as are the cases of bicycles and motorcycles, which are the main means of locomotion of the population.

The "many" signifier, which is inserted in the semantic field of "quantity", produces a silencing sense of the quantity and depth of difficulties faced by professional health subjects.

The discursive sequence "how do we get to the units when our access roads are spoiled?" Calls for both individual and collective introspection on the transport phenomenon and leaves evidence that its problem is not only related to its lack, but also to the poor conditions of roads, which aggravate the difficulty of accessibility to health units.

The discursive sequence highlighted "and some patients live very far away" produces indirect senses of the difficulty of the subjects affected by TB in accessing the health units; of late diagnosis; and the difficulty of TB control.

The denunciation of the geodemographic reality is represented in the following discursive sequence: "we know that in the Mozambican reality". The signifier "we" makes the sense that all Mozambicans know that a good part of them live far from the health unit. In the linguistic marks "they have lived more than $8 \mathrm{~km}$ ", observes the subjected subject by its ideology and that went through a socio-historical experience. In this case, the sequence produces the sense that people living for more than $8 \mathrm{~km}$ present difficulties from the identification of the symptoms to the treatment of the disease. This requires a policy design that can help reduce the distances that prevent the detection and consequent reporting of cases.

The "voice" of "long distances" reappears in the discursive sequence "it has distant health units, without laboratories". The "far-off" laboratory discourse labels leave evidence and a sense production of the lack of detection and care for the sick and suspected of TB.

\section{Reporting of cases for decision-making}

From the following cuts, we observe the denunciation of how the information is compiled.

There are record books in the sanitary units and then each health unit compiles the information according to the model of the Ministry, so we have the meeting and compile the data in a summary form, both in manual and electronic compilation and we take the province for planning. (PS10)

It is pointed out in the above clipping that the actions of compiling the information in a manual or electronic file suggest both the double registration that can guarantee the data conservation and the incipient process of the use of electronic means that are being introduced in those districts belonging to the rural area of Mozambique. Significant "we take the province for planning" lead to understand that the information on the reporting of the cases assists in the decision making for the planning of activities on TB reporting.

From the discursive sequence below, it is observed that the reporting system of case reports seems to have the purpose of controlling the performance of health professionals and not to give the real situation of TB in the districts and in the province as can be deduced:

But quarterly the peripheral health unit is [...], compiles the data [...], sends it to the district level and sends it to the province. This receives analyzes and gives feedback from what has to be agreed and then sends it to the central level in DOTS and other TB areas. After that, within 45 days the central level has to tell the provinces what the feedback is in terms of performance, what has happened well or not, and how it should improve. (NPS14)

From the discursive sequence "but quarterly the peripheral health unit is ... compiles the data [...], sends it to the district level and [...] sends it to the province", it can be deduced that the subject-position, summoned by ideology and interdiscourse, as the already-mentioned, is inscribed in a discursive formation that focuses on the upward and downward communication as aspects inscribed institutionally in the process of reporting of TB cases. The action of sending information to the district and to the province produces meanings that mean upward communication, which starts from the basis for those responsible.

On the other hand, it is observed a downward communication symbolizing norms, orders and at the same time producing an evaluative and evaluative sense, that is, the information that constitutes the feedback at the same time serve to evaluate, qualify and value the performance of the employees: "The central level has to tells the provinces what the feedback is in terms of performance, what has happened well or not and how it should improve." The discursive sequence "gives feedback on what has to be right" states/announces the controlling discourse invested with a domineering, evaluative paradigm.

It can be understood from the following statement that the flow of information regarding reporting has had some difficulties.

However, this flow has had irregularities, unfortunately is not processed within these periods, because there is a high turnover of human resources in TB. It is a difficult program to manage and often people who are placed as district managers in less than 2 years have to change. So there has to be new HR training and adaptation. So the time the information takes from the district to the province and the province to rectify, above all there are new district managers, and to get here takes time. And arriving here, at the central level, 
also has its mistakes. We have to do the feedback to ask you to look at certain data from districts A or Z are not correct and this ends up taking more than 45 days. (MS12)

The discursive sequences "this flow has had irregularities; is not processed within these periods ", under these conditions of production, denounces the failure to send information to higher levels. These same statements bring an indicative paradigm that suggests the lack of use of modern technology for the fluid transmission of information related to the reporting, indicating that the information only reaches the province with the displacement of the heads of the health units. The discursive sequence "there is a high HR turnover in TB" indicates a lagged coordination between the NTCP managers in the province and the HR managers responsible for the movement of health professionals, as evidenced in the following words: "it is a difficult program to manage and often people who are placed as district managers in less than 2 years have to change." In this sense, these statements make it necessary to train professionals to act in TB control, but who can act specifically in this area and for long periods and, if they are transferred, they are given the possibility of continuing to work in the area and contributing to the control of TB in other places. Also, the "difficult to manage" signifiers suggest a health system with difficulties in articulating the various existing programs.

\section{DISCUSSION}

In this study, a discursive analysis was carried out on the obstacles in the process of detection and reporting of tuberculosis cases in Mozambique. In this context, from the fragments presented, they are findings of the study: the low number of cases of TB is related to lack of material, human and transportation resources; with inadequate reporting and information system; and the lack of policies that focus on resolving the TB problem and adequate infrastructures.

In the first discursive block, it is observed that the health professional (MS1), taking the position of manager, is questioned by the circulating senses anchored in the speech that Mozambique is one of the countries with critical problems of laboratories, infrastructures and modern technologies ${ }^{(1,13)}$. The lack of sufficient laboratories in Sub-Saharan Africa, of which Mozambique is a part, seriously compromises the detection and reporting of TB $\operatorname{cases}^{(1,8,13)}$. It should be noted that this reality is also present in other countries with high TB burden, such as Nigeria, South Africa and Zimbabwe ${ }^{(1)}$.

The reporting rate in Mozambique remains only $34 \%$, making it worrying since it makes it impossible to know the true magnitude of the disease ${ }^{(13)}$. The worldwide TB case detection rate has stagnated by about $60 \%$, failing to reach the target of $70 \%$ originally planned for $2000^{(1)}$.

The senses produced by MS3 subject discourse concerning the difficulty of functioning and coverage of the laboratories and the shortage of evaluation instrument and trained professionals point to the need to elaborate policies that focus the sufficient financing for this activity and the training and qualification of the technicians, aiming in this way to increase the reporting of the cases. The literature emphasizes that managers need to make efforts to capture more resources for action and to obtain new knowledge ${ }^{(1)}$, which have been of great importance in the detection and reporting of $\operatorname{cases}^{(13)}$. A study carried out in Mozambique revealed that health professionals still have difficulties in knowing about patient characteristics, diagnosis and treatment of $\mathrm{TB}^{(14)}$, a situation that suggests the need for constant training of professionals in this area.

Infrastructure is another important factor in detecting and reporting cases. In places where it is deficient and scarce, the detection and reporting of cases have also proved to be inefficient, which requires the design of policies that focus on the construction of adequate infrastructures for the treatment of $\mathrm{TB}^{(1,7-8,10)}$.

The inadequate biosafety conditions stated/announced by subject PS4 were also reported in another study in Mozambique, which revealed that guidelines for diagnosis and treatment of TB were not present in all facilities, and few health facilities had ventilation ${ }^{(15)}$.

Still in the list of difficulties in detecting and reporting cases, MS11's speech signals the need for operational research, as it will provide better estimates of disease incidence and identify program deficiencies and priority areas for action ${ }^{(16)}$.

The low reporting in children signaled in the speech of the subject PS2 reflects the insufficiency of means not only for the control of TB, but also of other diseases, which has been recurrent in Mozambique ${ }^{(1)}$. In the ideological production conditions that permeate TB, the reporting of children's cases is related to the fact that the natural difficulties inherent to the diagnosis in children require even more attention from the professionals ${ }^{(1)}$. Furthermore, TB in childhood continues to be neglected, and the lack of estimates for childhood perpetuates and amplifies the problem ${ }^{(13)}$. These diagnostic difficulties in children also relate to the increased prevalence of HIV in children ${ }^{(16)}$.

From the speech of the MS13, it is noted that the subject could not speak of all the difficulties faced and, "taking advantage" of the bore of language, enunciated the adverb (many) that, besides silencing, can also produce the sense of repression. It is worth mobilizing Foucault's argument: "It is well known that one does not have the right to say everything, that one cannot speak at all in any circumstance, which anyone, in short, cannot speak of anything"(17). In these conditions of production, difficulties "passed" into the ambit of habits and customs, which, because they had never been solved, ceased to constitute novelty, so they were not part of worries or emergencies much less urgent to the point that the subject did not need to mention. In this context, the difficulties of access to health services contribute to the late diagnosis and treatment of the disease and delay the reporting of cases $^{(18)}$.

The words of MS13, MTS15 and MTS8 leave traces that the lack of transport and the long distances associated with the absence of laboratories lead to an increase in the spread of the disease and higher costs for patients undergoing treatment ${ }^{(19-20)}$. Likewise, the lack of transportation is pointed out by some authors as an obstacle in adherence to treatment ${ }^{(21)}$; and in a context such as Mozambique, where transport is a serious problem and where reported cases annually are less than 
estimated $^{(14)}$, the mobilization of various sectors such as education, health and transport to control TB can be important in increasing detection and reporting of $\operatorname{cases}^{(21)}$. A review of the detection and reporting system should be done by focusing on the increase of laboratories and qualified professionals as well as a double registration of cases that guarantees the validity of information beyond the modernization of the means of records. This will allow the provincial level to have immediate access to information, which requires the use of internet and other modern technological means in all health units ${ }^{(22)}$.

From the speeches of MS12 and NPS14 on the way information circulates, it signals a controlling discourse invested with a dominant and evaluative paradigm, thus suggesting that the information provided is linked to the obligation and not necessarily to compliance with the norms ${ }^{(17)}$. This situation requires a new strategy of information dissemination and the discussion of information for common use; standardized data collection, compilation and analysis can be used in health facilities to monitor treatment outcomes at the district level, with a view to identifying local problems that may arise at the provincial or national level and order to consistently ensure the control of $\mathrm{TB}^{(1,13)}$.

\section{Study limitations}

The study with only a few health professionals (managers, physicians, nursing professionals and medical technicians), leaving aside the laboratory workers, Community Health Agents, patients and the community, can be pointed out as possible limitation of the study, because it brings only the experiences of some and not everyone involved in the TB case detection and reporting process.

\section{Contributions to the area of nursing, health or public policy}

From the words of the subjects involved in the study it can be concluded that the research brings important discussions: difficulties of case detection, lack of transportation, long distances, underreporting - situations that can be verified not only in Mozambique but also in other countries with high TB load. It is important to note that the words, which constitute findings, have a great contribution both to the nursing area and to public health in general, because, besides adding knowledge, they contribute to the elaboration of policies that can focus on the detection of cases, treatment and improvement of information systems, which are elements for decision-making for TB control.

\section{FINAL CONSIDERATIONS}

From the symbolic material analyzed, it is pointed out that the discourses point to the ideological affiliation that includes the lack of investment policies in the health sector and the political commitment, taking these absences as basic obstacles in the detection and reporting of cases of tuberculosis, which is represented by insufficient microscopes and human resources, long distances, communication difficulties, among other factors. This requires policy design and implementation in order to reverse the country's current TB situation.

\section{FUNDING}

This research was funded by the Coordination for the Improvement of Higher Education Personnel (CAPES).

\section{REFERENCES}

1. Word Health Organization. WHO. Global Tuberculosis control: 2016[Internet]. Geneva: World Health Organization; 2016[cited 2016 Dec 13]. Available from: http://apps.who.int/iris/bitstream/10665/250441/1/9789241565394-eng.pdf?ua= 1

2. Brasil. Ministério da Saúde. Secretaria de Vigilância em Saúde. Programa Nacional de Controle da Tuberculose. Manual de recomendações para o controle da tuberculose no Brasil. Brasília: Ministério da Saúde; 2011

3. Fátima R, Harris RJ, Enarson DA, Hinderaker SG, Qadeer E, Ali K, et al. Estimating tuberculosis burden and case detection in Pakistan. Int J Tuberc Lung Dis [Internet]. 2014[cited 2016 Sep 15];18(1):55-60. Available from: http://ntp.gov.pk/uploads/ TB_prevalence_Pakistan_IJTLD-2014.pdf

4. Oshi DC, Chukwu JN, Nwafor CC, Meka AO, Madichie ON, Ogbudebe CL, et al. Does intensified case finding increase tuberculosis case notification among children in resource-poor settings? a report from Nigeria. Int J Mycobacteriol [Internet]. 2016[cited 2016 Oct 10];5(1):44-50. Available from: http://www.sciencedirect.com/science/article/pii/S2212553115001612

5. Rocha MS, Aguiar FD, Oliveira GP, Saraceni V, Coeli CM, Pinheiro RS. Confiabilidade do desfecho do tratamento, usando linkage de bases de dados para a tuberculose. Cad Saúde Colet [Internet]. 2015[cited 2016 Sep 1];23(2):150-6. Available from: http:// www.scielo.br/pdf/cadsc/v23n2/1414-462X-cadsc-23-2-150.pdf

6. Avilov KK, Romanyukha AA, Borisov SE, Belilovsky E M, Nechaeva O, Karkach AS. An approach to estimating tuberculosis incidence and case detection rate from routine notification data. Int J Tuberc Lung Dis [Internet]. 2015 [cited 2016 Out 17];19(3):288-94. Available from: https://www.ncbi.nlm.nih.gov/pubmed/25686136

7. Cown J, Michel C, Manhiça I, Monivo C, Saize D, Creswell J, et al. Implementing rapid testing for tuberculosis in Mozambique. Bull Word Health Organ [Internet]. 2015[cited 2016 Sep 25];93(2):125-30. Available from: http://www.who.int/bulletin/ volumes/93/2/14-138560.pdf

8. Hoog AHV, Laserson KF, Githui WA, Meme HK, Agaya JA, Odeny LO, et al. High prevalence of pulmonary tuberculosis and inadequate case finding in Rural Western Kenya. Am J Resp Crit Care Med[Internet]. 2011[cited 2016 Nov 18];181(9):45-1253. Available from: http://www.atsjournals.org/doi/pdf/10.1164/rccm.201008-1269OC 
9. Valencia MS, Cezar-Vaz MR, Bruns CB, Silva PEA. O processo de detecção e tratamento de casos detberculose em um presidio. Cienc Saúde Colet[Internet]. 2016[cited 2016 Sep 28];21(7):2111-22. Available from: http://www.scielo.br/pdf/csc/v21n7/14138123-csc-21-07-2111.pdf

10. Sanale A, Mergentheler C, Nasrat A, Seddlq MK, Mohmodl SD, Stevens RH. An evaluation of passive and active approaches to improve tuberculosis notifications in Afeghanistan. PLoS One [Internet]. 2016[cited 2016 Sep 23]; 11(10):e0163813. Available from: https://www.ncbi.nlm.nih.gov/pmc/articles/PMC5049786/pdf/pone.0163813.pdf

11. Orlandi EP. Análise de Discurso: princípio \& procedimentos. 11ª ed. Campinas: Pontes Editores; 2013.

12. Fernandes CA. Análise do Discurso: Reflexões introdutórias. $2^{\text {a }}$ ed. São Carlos: Claraluz, 2008

13. Ibanês AS, Carneiro Jr N. Panorama internacional da estratégia do tratamento diretamente supervisionado (DOTS) nas políticas de controle de TB. ABCS Health Sci [Internet]. 2013[cited 2016 Dec 10];38(1):25-32. Available from: http://files.bvs.br/ upload/S/1983-2451/2013/v38n1/a3661.pdf

14. Noé A, Ribeiro RM, Anselmo R, Maixenchs M, Sitole L, Munguambe K, et al. Knowledge, attitudes and practices regarding tuberculosis care among health workers in Southern Mozambique. BMC Pulmonary Med[Internet]. 2017 [cited 2017 Jun 23];17:2. Available from: https://www.ncbi.nlm.nih.gov/pmc/articles/PMC5217625/pdf/12890_2016_Article_344.p

15. Brouwer M, Coelho E, Mosse CD, Brondi L, Winterton L. Leth FV. Health Care Workers Challenges in the implementation prevention and control Measures in Mozambique. Plos One [Internet] 2014[cited 2016 Dec 3];9(12):e114364. Available from: http://journals.plos.org/plosone/article/file?id = 10.1371/journal. pone.0114364\&type $=$ printable

16. García-Basteiro AL, Lópes-Varela E, Manhiça I, Macete E, Alonso PL. Mozambique faces challenges in the fight against tuberculosis. Lancet[Internet]. 2014 [cited 2016 Oct 30];383:214-6. Available from: http://www.thelancet.com/pdfs/journals/lancet/PIIS01406736(14)60069-6.pdf

17. Foucault M. Vigiar e punir: nascimento da prisão. 42ª ed. Petropolis, Rio de Janeiro: Vozes, 2014.

18. Trébucq A, Schwoebel V. Numbers of tuberculosis cases dreams and reality. Int J Tuberc Lung Dis [Internet]. 2016[cited 2016 Oct 30];20(10):1288-92. Available from: http://www.ingentaconnect.com/content/iuatld/ijtld/2016/00000020/00000010/art00007

19. Hiatt T, Nishikiori N. Epidemiology and control of tuberculosis in the Western Pacific Region: update with 2013 case notification rate. WPSR [Internet]. 2016[cited 2016 Oct 27];7(2):41-50. Available from: http://ojs.wpro.who.int/ojs/index.php/wpsar/article/ view/416/668

20. Boss JC, Smalbraak L, Macome AC, Gomes E, Leth FV, Prins JM. TB diagnostic process management of patients in a referral hospital in Mozambique in comparison with the 2007 WHO recommendations for the diagnosis os smear-negative pulmonary TB and extrapulmonary TB. Int Health[Internet]. 2013[cited 2016 Oct 11];5(4):302-8. Available from: https://www.ncbi.nlm.nih. gov/pubmed/24130098

21. Cardoso GCP, Cruz MM, Abreu DMF, Decotelli PV, Chrispim PPM, Borenstein JS, et al. A conformidade das ações do tratamento diretamente observado para tuberculose na perspectiva dos profissionais de duas unidades de saúde da cidade do Rio de Janeiro. Cad. Saúde Colet[Internet]. 2012 [cited 2017 Jun 20];20(2):203-10. Available from: http://www.cadernos.iesc.ufrj.br/cadernos/ images/csc/2012_2/artigos/csc_v20n2_203-210.pdf

22. Laokris S, Drabo MK, Weil O, Kafando B, Dembélé SM, Dujardin B. Patients are paying too much for tuberculosis: a direct cost burden evaluation in Burkina Faso. Plos One [Internet]. 2013[cited 2016 Nov 10];8(2):e56752. Available from: https://www.ncbi. nlm.nih.gov/pmc/articles/PMC3581516/pdf/pone.0056752.pdf 